\title{
A Laszkij-féle permi térkép digitális fakszimileváltozata
}

\author{
Gulyás Zoltán
}

DOI: https://doi.org/10.30921/GK.71.2019.2.3

Absztrakt: A cikk szerzóje bemutatja a Permi kormányzóság részletes térképét, amelyet Laszkij oroszországi járási földmérố készitett a 19. század közepén. A kéziratos térképet Reguly Antal (1819-1858) nyelvész, etnográfus részére adták át, aki az 1843 és 1845 között véghezvitt északi-uráli utazása és térképezö munkálatai során felhasználta a müvet a terepen. Laszkij térképe - amelyet a Reguly-hagyaték részeként napjainkban Budapesten óriznek - a rajta feltüntetett korabeli földrajzi nevek, igazgatási határok, postaállomások és ipari települések révén még ma is fontos forrásul szolgál az uráli vidékek megismerését célzó történeti-földrajzi kutatásokhoz. A szerzó nemcsak elemzi a kevéssé ismert kéziratos térképet, hanem a modern kartográfia eszközeit felhasználva egyúttal el is készíti annak digitális fakszimile változatát. A szerzố konkrét példák megemlítésével, illetve a Laszkij-féle térkép feldolgozásának rövid ismertetésével hívja fel a figyelmet a kartográfia alkalmazásának lehetôségére kulturális értékeink megörzésében.

Abstract: The author of the paper presents a detailed map of Perm Governorate prepared by Laskiy, a Russian district land surveyor in the middle of the 19th century. The manuscript map was given to Antal Reguly (1819-1858), a Hungarian ethnographer and linguist, who used it on the field by travelling to the northern Ural Mountains and mapping the land between 1843 and 1845. Laskiy's map is kept in Budapest as a part of Reguly's heritage and can be considered an important source of information for several historical-geographical studies about the Ural region even today, particularly due to its representation of the contemporary names of geographical features as well as administrative boundaries, postal offices and industrial settlements. The author not only analyses the less known manuscript map, but also prepares its digital facsimile version by using modern cartographic techniques. In order to draw attention to the possible application of cartography in saving cultural heritage, he gives some examples and brief description of the processing of Laskiy's map.

Kulcsszavak: digitális fakszimile, feldolgozás, alkalmazott kartográfia

Keywords: digital facsimile, processing, applied cartography

\section{Bevezetés}

A régi térképek tanulmányozása gyakran megnövelheti azoknak a jelenkori kutatásoknak az eredményességét, amelyek egy-egy közigazgatási egység történeti földrajzának minél alaposabb megismerésére irányulnak. Az értékes információkat közvetítố tartalmi elemek megfeleló értelmezéséhez esetenként szükségessé válhat a régi térkép korszerú újraalkotása a mai olvasókhoz közel álló ábrázolási megoldásokkal. Jelen tanulmányomban a több mint 175 éves, kartográfiai szempontból mind ez idáig feltáratlannak számító Laszkij-féle permi térképpel foglalkozom, amelynek kéziratos példánya Reguly Antal hagyatékának részeként maradt fenn. A kulturális értékmentés jegyében nem csupán górcsố alá vettem a Permi kormányzóságot bemutató, ritkaságszámba menô térképet, hanem egyúttal elkészítettem annak digitális fakszimile változatát is.

\section{Történeti áttekintés}

Felvetődik a kérdés, hogy egy egykori uráli igazgatási egységet szemléltető, oroszországi szerzô által szerkesztett 19. századi térkép miként kapcsolódik a magyar kultúrtörténethez? Mit tudhatunk a keletkezési körülményeirôl, továbbá a térképet illetôen történtek-e már vizsgálatok a hazai kartográfusok részéról, és ha igen, ezek milyen eredményekkel szolgáltak? A térkép részletes elemzése elôtt szükségesnek tartom, hogy mindezekrôl rövid történeti áttekintést nyújtsak.

A magyar nyelvrokonság iránt érdeklôdő Reguly - az útinaplójának tanúsága szerint - 1843. november 7-én érkezett meg Permbe, amely város egyaránt kezdete és végpontja volt a szúkebb értelemben vett uráli és nyugatszibériai utazásának (Reguly 2008). A fiatal magyar utazó a városban Ogarjov ${ }^{1}$ kormányzó személyes vendége volt, és a helyi hivatalnokok részérôl is kitüntetett figyelemben részesült. November 9-én Prjagyilscsikovtól ${ }^{2}$ megkapta a

\footnotetext{
1 Ogarjov, Ilja Ivanovics [Szaratovi kormányzóság, 1780. ? ? - Perm, 1854. május 6. (május 18.)]: orosz politikus, katonatiszt titkos tanácsos. Kormányzói tisztségben 1831-1837 között az Arhangelszki, majd 1837-tôl haláláig a Permi kormányzóság vezetôje.

2 Prjagyilscsikov, Fjodor Afanaszjevics [Ocsor, 1811. január 26. (február 7.) - Ocsor, 1870.
}

kormányzóság településneveinek jegyzékét, két nappal késôbb pedig a kormányzó utasítására egy térképet adtak át Regulynak. Ez utóbbi munka a Permi kormányzóságot ábrázoló, 1843-ban összeállított térkép, amelyet a Regulytérkép egyik fontos forrásmúveként tartanak számon. Szerzójét tekintve a térkép jobb alsó sarkában orosz nyelvú megírás jelzi, hogy Laszkij járási földmérô készítette, és - ugyancsak járási földmérôi minôségben - Morev ellenórizte. A térkép címmezóje alatt a permi kormányzósági földmérô, Kittari ${ }^{3}$ aláírása szerepel 1843-as évszámmal. Az orosz nyelvú kéziratos térkép napjainkban az MTA Könyvtár és Információs Központ Kézirattárában lelhetô fel (Laszkij 1843).

A hazai térképész-szakirodalomban elsôként Borbély Andor tett említést

december 17. (december 29.)]: orosz hely történész, krónikaíró, pedagógus. A Permi kormányzóság történetének jeles kutatója.

3 Kittari (Kittara), Jakov Francevics [?-?]: nemesi származású oroszországi mérnök Pályája kezdetén járási földmérôként dolgozott Kungurban és Krasznoufimszkban. 1822-ben elkészítette Perm város térképét 1835-1845 között Permben a kormányzósági földmérối tisztséget töltötte be. A neves természettudós, kazanyi egyetemi tanár, Mogyeszt Kittari (1825-1880) édesapja. 
a permi térképrôl, amelyet a Reguly uráli térképezésével foglalkozó tanulmányában Laszky-féle térképnek nevezett (Borbély 1955). A Regulyhagyaték dokumentumait szemrevételezve Borbély arra a megállapításra jutott, hogy a térképet a permi helynévlistával együtt a kormányzóság hivatalnokai készítették el és bocsátották Reguly rendelkezésére, aki az adatokat bôségesen felhasználta saját térképén a néprajzi határok ábrázolásához. Borbély ugyanakkor nem vizsgálta a permi térkép tartalmi elemeit, mindössze a Reguly-térkép egyik lehetséges forrásaként hivatkozott a munkára.

Bô fél évszázaddal később, a Reguly születésének 190. évfordulójához kapcsolódó megemlékezések részeként két térképészeti publikáció is napvilágot látott, ahol utalást találhatunk a permi térképre. Az egyik Klinghammer István és Gercsák Gábor írása, amelyben a szerzők - részben Borbély tanulmányának nyomán - ugyancsak felsorolták a Reguly-térkép forrásait, és ezek között Laszkij-féle orosz szövegú kéziratos térképként említették meg a múvet (Klinghammer-Gercsák 2009). A másik publikáció Márton Mátyás tollából származik, aki nem csupán megnevezte, hanem a Regulytérképhez fúzôdố vizsgálataiba be is vonta a permi térképet, sốt annak egy hegyvidéki részletérôl összehasonlítás gyanánt fényképfelvételt is közölt (Márton 2009). Munkájában Márton rámutatott az eredeti kéziratos Regulytérkép és a permi térkép domborzatábrázolásának hasonlóságára, valamint azt is megjegyezte, hogy a Laszkij-féle térkép Reguly térképe déli részének mindössze $4^{\circ}$-nyi széles, csonka sávját tartalmazza.

A Reguly-témában megírt doktori értekezésemben magam is szenteltem egy kisebb alfejezetet a Permi kormányzóság térképének (Gulyás 2016). Doktori kutatásaim során méréseket végeztem a térképen, illetve röviden ismertettem a fóbb tartalmi elemeit. A térképet készítő járási földmérô pontos kilétének meghatározására tett kísérleteim egyelốre még nem vezettek eredményre. A Permi Határterület Állami Levéltárának kérésemre kiadott közleménye szerint az intézményben nem maradtak fenn dokumentumok, életrajzi adatok Laszkijról. Az általam ez idáig megtekintett korabeli oroszországi kartográfiai munkákban sem találkoztam a földmérố nevével. Eddigi vizsgálataim alapján azonban nem tartom elképzelhetetlennek, hogy egy lengyel származású személyrôl van szó.

\section{A Permi kormányzóság}

Véleményem szerint a Laszkijféle térkép tulajdonságait és kartográfiatörténeti jelentőségét akkor ismerhetjük meg igazán, ha az ábrázolt terület földrajzi helyzetéról, közigazgatási beosztásáról is képet kapunk. Ennek megfelelôen az alábbiakban néhány általános információt adok közre a Permi kormányzóság vázlatos bemutatása céljából.

A Permi kormányzóság mint igazgatási egység 1796 és 1923 között létezett az Orosz Birodalom, majd a Szovjetunió részeként. Területének nagysága - a Jekatyerinburgi kormányzóság 1919-es kiválásáig - 332052 km² volt, amelynek nagyobbik része (kb. $181000 \mathrm{~km}^{2}$ ) a kormányzóságon keresztül észak-déli irányban végighúzódó uráli hegylánc nyugati oldalán, Európában helyezkedett el (1. ábra). A kormányzóság területére esett a mai értelemben vett Északi- és KözépsôUrál vonulata, több nevezetes csúccsal, mint például a Konzsakovszkij Kameny (1569 m), vagy a Reguly által is térképezett Gyenyezskin Kameny (1492 m). A kormányzóság jelentôs vízfolyásai között említhetjük meg az európai oldalán a Káma, a Pecsora és a Visera, míg az ázsiai oldalán a Lozva, a Szoszva, a Tura és az Iszety folyókat. A Permi kormányzóság méreteit jól mutatja, hogy területe a jelenkori Oroszország hét nagy igazgatási egységét is érinti (Baskír Köztársaság, Komi Köztársaság, Udmurt Köztársaság, Permi határterület, Szverdlovszki terület, Kurgani terület, Cseljabinszki terület), illetve két ma már egymilliónál nagyobb lélekszámú nagyvárost is magában foglal (Perm és Jekatyerinburg).

A Laszkij-féle térkép készítése, illetve Reguly látogatása idején a Permi kormányzóságot négy igazgatási terület határolta: északon a Vologdai, nyugaton a Vjatkai, keleten a Tobolszki, délen pedig az Orenburgi kormányzóság. A Permi kormányzóság adminisztratív központja Perm város volt, amely egyúttal a Permi járás székhelyéül is szolgált. A kormányzóság 12 járásra tagolódott, amelyek a központi településükrôl kapták a nevüket. A járások közül hét - Cserdinyi, Krasznoufimszki, Kunguri, Ohanszki, Oszai, Permi és Szolikamszki járás - a kormányzóság európai részéhez

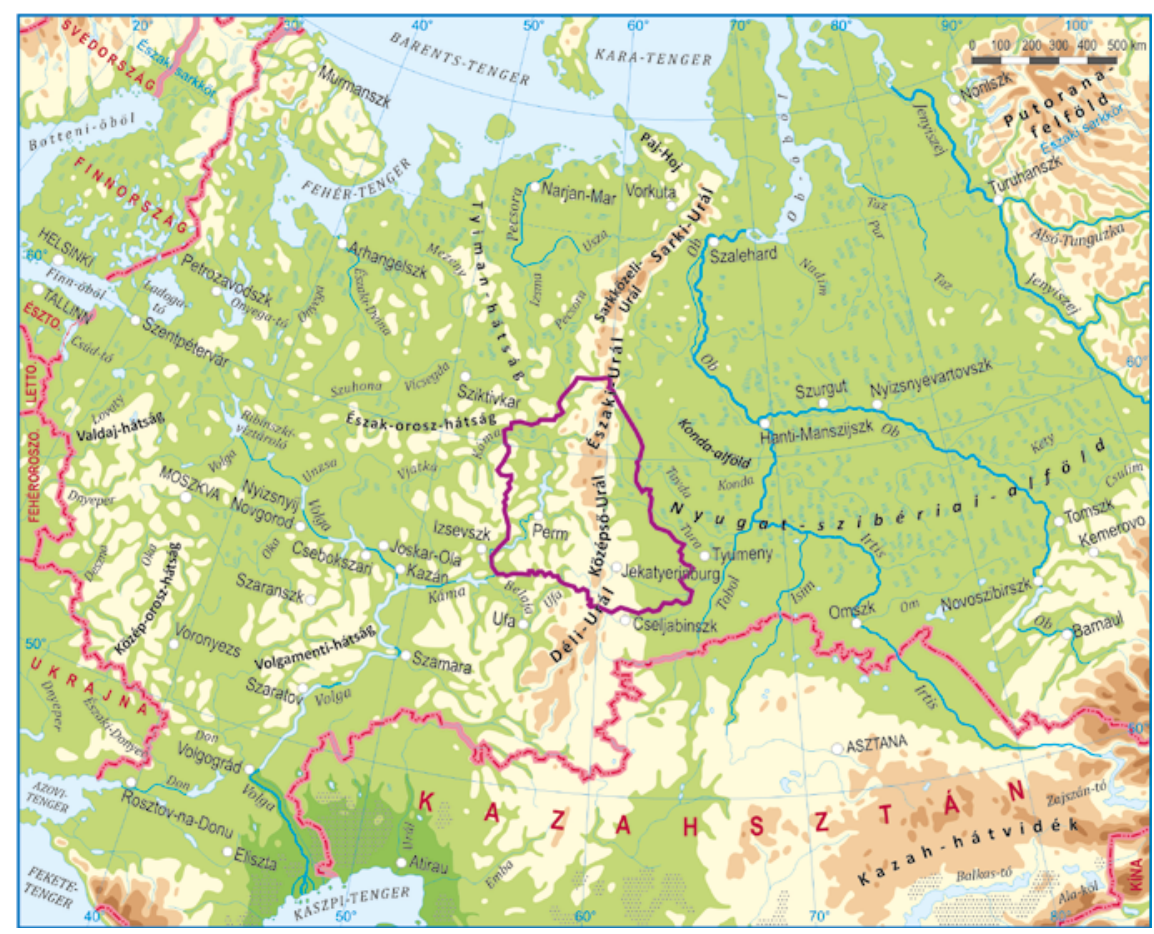

1. ábra. A Permi kormányzóság határainak szemléltetése egy mai térképen 
tartozott. Az ázsiai oldalon fekvố területi egységek - Irbiti, Jekatyerinburgi, Kamislovi, Sadrinszki és Verhoturjei járás - a Krasznoufimszki járással együtt 1919-ben az újonnan szervezett Jekatyerinburgi kormányzóság részévé váltak.

\section{A Laszkij-féle kéziratos térkép}

A kutatások jelenlegi állása szerint nincsen tudomásunk arról, hogy a Laszkijféle térképnek léteznek-e további fennmaradt változatai. A térképhez kapcsolódó részletes vizsgálataimat a Budapesten órzött kéziratos példány helyszíni tanulmányozása alapján végeztem el.

Laszkij alkotása - amelynek pontos címe Karta Permszkoj gubernyii, azaz a Permi kormányzóság térképe az északi szélesség 55-62 ${ }^{\circ}$, valamint a Ferrótól ${ }^{4}$ számított keleti hosszúság 71-82 ${ }^{\circ}$ közötti területeket mutatja be. Jellegét tekintve igazgatási szigettérkép, amely a kormányzóság 12 járását hatféle színfelülettel szemlélteti. Az 1167 × 891 mm lapméretú térkép vászonra kasírozott kivitelben készült, és hajtogatott formában $6 \times 4=24$ darab, közel azonos nagyságú, álló téglalap alakú részletből tevôdik össze. Az egyes téglalapokat $3 \mathrm{~mm}$-es hézagok választják el egymástól. A kettôs kerettel határolt térképnek a külsô keret által kijelölt mérete $1134 \times 857 \mathrm{~mm}$. A halványszürke kitöltéssel rendelkezô külsố keret $6 \mathrm{~mm}$ széles, amelytôl $5 \mathrm{~mm}$ távolságra helyezkedik el az 1,5 mm szélességú belsô keret.

A térkép északnyugati tájolású, nem tartozik hozzá jelmagyarázat, valamint a méretarányra és a vetületre utaló közlések is hiányoznak róla. A térkép méretaránya kb. 1 : 850 000. Földrajzi fokhálózata $1^{\circ}$-os beosztású, ferrói kezdômeridiánnal, amelyrốl a térkép alsó keretvonalának közepe táján egy rövid megjegyzés is tanúskodik. A Permi kormányzóság ábrázolása pontosan a térképlap közepéhez igazítva jelenik meg, és a határain túl a négy szomszédos kormányzóság nevének szórt

\footnotetext{
${ }^{4}$ Ferro (ma Hierro) a Kanári-szigetek leg nyugatabbi tagja. A ferrói kezdômeridián Greenwichtôl $17^{\circ} 40^{\prime} 46^{\prime \prime}$-cel nyugatra helyezkedik el.
}

megírásai olvashatók. A térkép címe nagy méretú verzál betúkkel a jobb felsô sarokban kapott helyet. A térkép bal alsó sarkában táblázatos megjelenítéssel a 12 járási központ egymáshoz viszonyított, versztben ${ }^{5}$ kifejezett távolságértékei vannak megadva, amelyeket esetenként vegyesszámalakban tüntettek fel.

A kéziratos térkép nyelve orosz, a földrajzi nevek és egyéb szöveges elemek a korabeli orosz helyesírásnak megfelelően kerültek fel rá. A térképen az orosz ábécé több olyan betújével is találkozhatunk, amelyek napjainkban már nincsenek használatban (mint például a jaty vagy a fita).

Tartalmát illetôen a térkép vízhálózata meglehetősen gazdag. A legnagyobb folyókat felületszerǔen, míg a kisebb vízfolyásokat fokozatosan vastagodó sötétkék vonalakkal ábrázolták. A folyók vonalát kis mértékben a kormányzósági határon túl is megrajzolták, ezzel is jelezve a vízfolyás futásának irányát. A tavak a kontúrvonalukat hangsúlyozó, kék színú részleges felületi kitöltést kaptak, de néhány esetben kitöltés nélkül is előfordulnak. A Laszkij-féle térkép mintegy 394 folyónevet és 19 tónevet tartalmaz. Mai szemmel nézve kissé szokatlannak tûnik, hogy a nagyobb folyók neveit szórt betúkkel írták meg.

A térképen a domborzat bemutatása sajátos és egyben igen szemléletes módon történik: az uráli vonulatok rajzolata az egyes magassági szinteknek megfelelô, plasztikus hatást kölcsönzô fogazott sávokból épül fel. A domborzatrajz nem zavarja a többi térképi elem olvasását és azonosítását. A domborzathoz fưzôdôen nincsenek bejelölve hegycsúcsok, hegynevek vagy magassági értékek. Mindössze egyetlen egy megírás szerepel, amely az uráli hegyláncra vonatkozik.

A térképen kétféle határkategóriát különböztethetünk meg - kormányzósági és járási határt. Az elôbbit két pont és egy szakasz, az utóbbit pedig egy pont és egy szakasz váltakozásából felépülố határvonalak jelölik. A járási határ mindkét oldalán vékony szalagok (ún. határbandok) futnak, amelyek színei a járások felületi kitöltéséhez

51 verszt (orosz mérföld) $=1067$ méter. igazodnak, kissé sötétebb színárnyalattal. A kormányzósági határ belsố oldalán a járás színének megfelelô vékony szalag, míg a külsố oldalon jóval szélesebb határband fut, amelynek színárnyalata három lépcsőben fokozatosan halványodik.

A Permi kormányzóság térképén több mint 2500 települést számoltam össze, amelyek bemutatásához - a hierarchiát kiválóan érzékeltető módon - hatféle jelkategóriát használtak. A járási központokat kereszttel ellátott, egymás mellett elhelyezkedô téglalapokból felépüló jelek mutatják. Külön kategóriát szenteltek három további településnek, a járásközponti státuszukat már korábban elveszítô Alapajevszk, Dalmatovo és Obvinszk városoknak, amelyek jelei ugyancsak kereszttel megjelölt téglalapból és egy településkarikából állnak össze. Azokhoz a helységekhez, amelyek a térkép szerint ipari üzemekkel rendelkeznek, egy nagy méretú, vékony vonalszakaszokkal sugárszerúen körberajzolt településkarika tartozik. Mellettük a településnévvel együtt az ipari tevékenységre (pl. vas-, arany- és rézolvasztás, márványfejtés, fûrészüzem) utaló rövidítések olvashatók. A templommal rendelkezó falvakat kereszttel kiegészített településkarikák szemléltetik, míg a kisebb falvak kétféleképpen tû́nnek fel: kis településkarikák, felettük függóleges vonallal vagy anélkül. A térképen jó néhány esetben láthatunk településjeleket megírások nélkül, vagy éppen ellenkezóleg, maga a jel hiányzik a településnév mellől.

Az utak közül csak a legfontosabbakat vették fel. A folytonosan meghúzott vonalakhoz szorosan kapcsolódnak a versztben kifejezett távolságértékek megírásai, sok esetben itt is vegyesszámalakban. A térképnek tematikus jelleget ad, hogy bejelöltek rajta 84 postaállomást, melyeket közvetlenül a településnevek mellett elhelyezett, kürtre emlékeztetô szimbólumokkal ábrázoltak, továbbá két fúrészmalmot és három folyóparti kikötőt. Ez utóbbiakat kis méretú horgonyokkal jelölték, és közülük kettô a Káma folyón, Szolikamszk térségében, a harmadik pedig az Ufa folyó felsô szakaszánál helyezkedik el. 
A térképen élénk barna tussal utólag berajzolták a Szolikamszk és Verhoturje közötti útszakaszokat. A tizenegy útszakasz közül tízhez távolságadat is tartozik, amelyek mellett a „W." latin betûs rövidítés utal a mértékegységre. A távolságok megírásainak alapos tanulmányozása után úgy gondolom, Reguly maga jelölte be a saját útvonalát a Permi kormányzóság térképén. Továbbá a térkép északi részén ceruzával halványan berajzolva megjelenik még néhány folyó vonala, latin betûs feliratokkal kiegészítve, amelyek nagyon hasonlítanak a magyar utazó kézírására. Valószínúnek tartom, hogy Reguly az uráli útján szerzett tapasztalatainak megfelelốen a későbbiekben bôvítette és pontosította a Permben kapott térképet.

Vizsgálataim során megállapítottam, hogy Reguly a részletes felmérésen alapuló Laszkij-féle térképrôl több topográfiai információt is átvett: részben ennek alapján rajzolta meg saját térképe nyugati oldalán a jelentôsebb vízfolyásokat, a kormányzóság határát, illetve négy járási központot (Cserdiny, Irbit, Szolikamszk és Verhoturje). Mindemellett a permi térképról ötleteket is merített a saját térképének ábrázolási megoldásaihoz.

\section{A digitális \\ fakszimileváltozat}

A Laszkij-féle térkép - azon túl, hogy a Reguly-hagyaték egyik értékes tételét képezi -önmagában is kiemelkedô alkotás, az uráli vidékek térképezésének fontos kordokumentuma. Páratlan tartalmi gazdasága révén a térkép számos olyan információt közöl a Permi kormányzóság 19. század közepén fennálló közigazgatási és földrajzi viszonyairól, amelyek közvetlenül hasznosíthatók a legkülönfélébb kutatásokhoz.

Amennyiben Laszkij térképét összehasonlítjuk a jelenkori kiadású kartográfiai munkákkal, megállapíthatjuk, hogy a kormányzóság területére nézve miként változott meg a településhálózat, illetve az egyes települések elnevezése és jogállása. A Laszkij-féle térképen nagy számban találhatunk településeket, amelyek napjainkban már nem léteznek, mivel az elmúlt
175 év alatt fokozatosan elnéptelenedtek. Olyan esetre is akad példa, amikor bizonyos helységek egészen más okból szúntek meg: a Kámai-víztározó 1954-es megépítésének eredményeként a kormányzóság területén több 17. századi alapítású - vagy még annál is régebbi - település víz alá került (például a Sztroganovok ${ }^{6}$ által alapított, sótermelésérôl nevezetessé vált Uszolje város jelentôs része). A térkép jól szemlélteti a Káma futását és a kormányzóság vízfolyásainak hálózatát a folyószabályozások elôtti állapotoknak megfelelóen. Tartalmi elemeit tanulmányozva képet kaphatunk a korabeli uráli ipari központokról, ezáltal a térkép a helytörténeti kutatások számára is eredményesen használható. A térkép nagy mennyiségú földrajzinévanyagának vizsgálata névtani kutatásokat is megalapozhat. Annak érdekében, hogy a Laszkij-féle térkép tartalma minél inkább ismertté és elérhetôvé váljon, szükségesnek láttam a kéziratos alkotás korszerú kartográfiai és névrajzi feldolgozását.

A modern kartográfiai szemléletmód és az informatika eszközeinek együttes alkalmazása nagyban segítheti kulturális értékeink megôrzését, illetve közvetítését az érdeklôdô közönség részére. Az értékmentés egyik hazai példájaként említhetô meg a Rónai András ${ }^{7}$ szerkesztésében készült Közép-Európa Atlasz számítógépes feldolgozása. Az atlasz elsố kiadása 1945-ben, digitális fakszimile változata pedig 1993-ban jelent meg (Rónai 1993). A Közép-Európa természeti és társadalmi jellemzôit bemutató szöveges atlasz elsố kiadását a háborús körülmények miatt nem sikerült az eredeti terveknek megfelelően befejezni, mindössze csekély példányszámban, kedvezôtlen technikai feltételek

\footnotetext{
6 Orosz kereskedô és földbirtokos család. Fontos szerepet játszottak Jermak Tyimofejevics atamán 1580-as években vezetett szibériai hódítóútjának megszervezésében. Későbbi vagyonos nemzedékeik tagjai az arisztokrácia soraiba emelkedtek. A 16-20. századi Oroszország politikai, gazdasági és kulturális életének meghatározó személyiségei voltak.

7 Rónai András [Nagyszeben, 1906. június 13. - Budapest, 1991. augusztus 13.]: földrajztudós, geológus. Az Államtudományi Intézet munkatársa, 1940-1945 között igazgatója Politikai-földrajzi munkássága mellett a hidrogeológia és a negyedidôszaki földtan területén is kimagasló eredményeket ért el.
}

közepette látott napvilágot. Közel fél évszázaddal késóbb az újabb kiadás elkészítésének gondolata abból eredt, hogy a technikai fejlődés lehetôvé tette az atlaszban testet öltött értékes szellemi munkának az eredetinél nagyságrendekkel jobb minôségben történô megjelentetését. Az atlasz térképei az ELTE Térképtudományi Tanszékén készültek, Zentai László vezetésével. A készítők szándéka nem az eredeti atlaszlapok változatlan újraalkotása, hanem a kartográfiai és rajzi pontatlanságokat kiszúrô, tartalomhú fakszimilék létrehozása volt (Zentai 1993). Összességében elmondható, hogy a feldolgozásnak köszönhetốn ez a maga nemében egyedülálló atlasz a mai olvasók igényeihez igazodó, széles körben ismert kiadvánnyá vált.

Kartográfiai értékeink megőrzésében és népszerúsítésében igen jelentős szerepet játszik a Virtuális Glóbuszok Múzeuma, amelynek létrehozása Márton Mátyás (alapító szerkesztô) és Gede Mátyás (technikai megvalósító) nevéhez füződik (Márton 2008). A virtuális gyújteményben egyaránt fellelhetôk a magyar glóbuszkészítés történetének jeles darabjai és a hazai térképtárakban ôrzött, nagy értéket képviselô glóbuszok. Az értékmentô munka során az eredeti glóbuszok alapján virtuális fakszimileváltozatok készülnek, amelyek a múzeum internetes oldalán a nagyközönség számára is elérhetôvé válnak. A gyújteményben tekinthetố meg a magyar kulturális örökség jeles emlékének, Perczel László $^{8}$ - Reguly és Laszkij kortársa nagy méretú földgömbjének korszerú feldolgozása is.

Kutatásaim keretében - az elốzóekben említett példákat is figyelembe véve - elkészítettem a Laszkij-féle térkép digitális fakszimileváltozatát (2. és 3. ábra). A munkálatok folyamán a térkép valamennyi grafikus elemét a mai olvasókhoz közelebb álló ábrázolási megoldásokkal újrarajzoltam, a saját olvasatomban feltárt névrajzi elemeket pedig nyomtatott betúkkel megjelenítettem. A digitális fakszimileváltozatot

\footnotetext{
8 Perczel László [Bonyhád, 1827. július 11. Péterháza, 1879. május 9.]: politikus, katonatiszt. Kömlődi birtokán készített óriás földgömbje az 1881. évi velencei III. Nemzetközi Földrajzi Kongresszuson aranyérmet nyert
} 


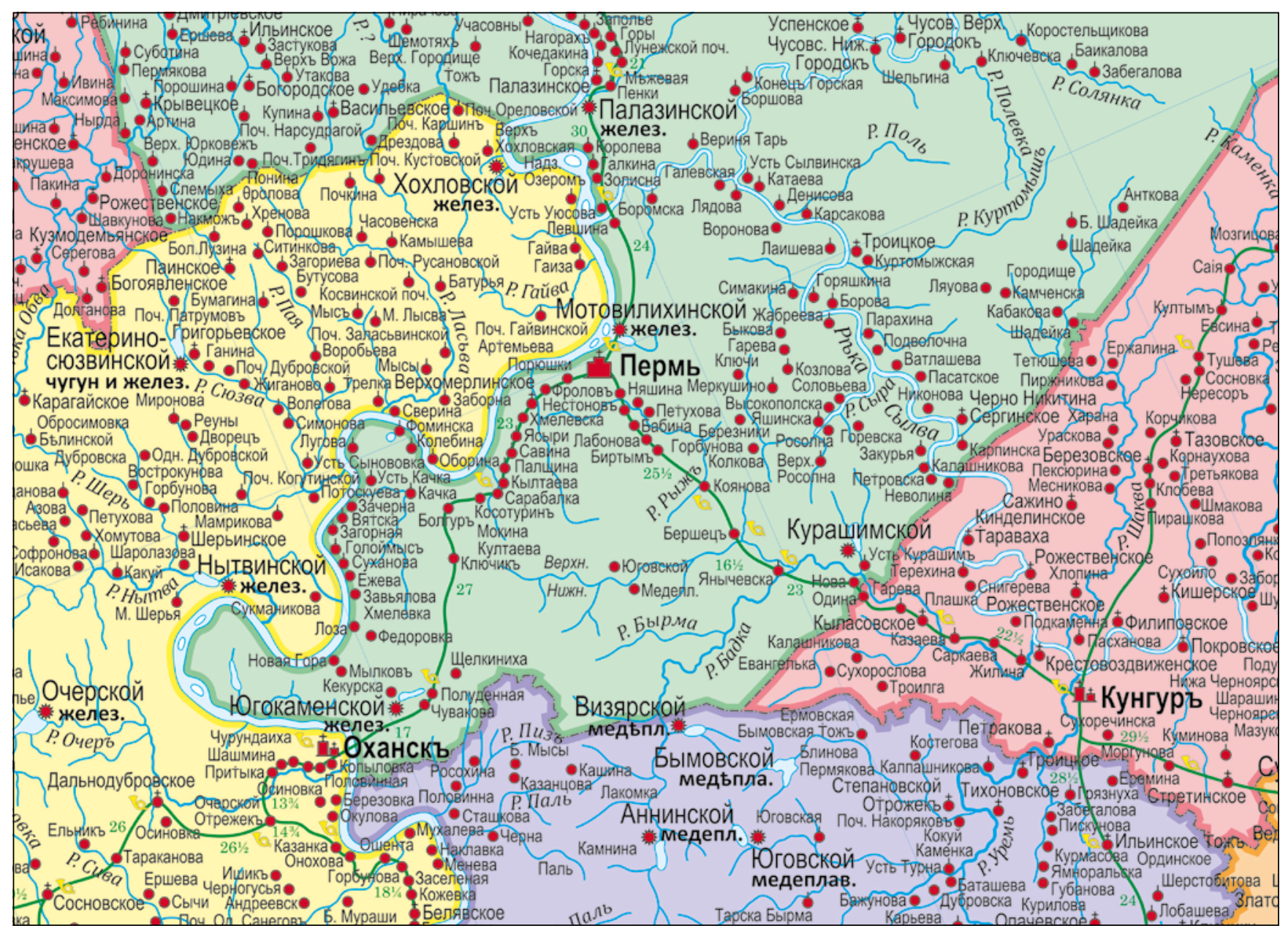

2. ábra. Perm város és a szomszédos területek a digitális fakszimile változaton

az eredetivel megegyezô méretben, viszont hézagok nélkül, a téglalap alakú részletek egybeszerkesztésével alkottam meg. Mindemellett a térképet magyar és orosz nyelvú jelmagyarázattal is elláttam. A földrajzi fokhálózatra támaszkodva keresôhálózatot alakítottam ki, ezáltal egy betúből és egy számértékből képzett azonosító segítéségével minden egyes névelem egyszerűen visszakereshetô. A digitális technológia elônye legfốképpen a névrajz bemutatásában nyilvánul meg: a nehezen olvasható kéziratos megírásokkal ellentétben a meglévő betűkészletek összehasonlíthatatlanul nagyobb választékkal szolgálnak. A betűk méretét és tulajdonságait oly módon választottam meg, hogy a különbözó természetû földrajzi nevek egymástól jól elkülönüljenek, ezáltal a vonatkozási helyük is könnyebben felismerhetô legyen. Nagy súlyt fektettem a tematikus tartalom minél látványosabb szemléltetésére. Az ipari településeket még inkább kiemeltem, valamint a postaállomások és a kikötők jelméretét is megnöveltem.

A digitális fakszimileváltozat mellé névjegyzéket is összeállítottam, amely a térképen szereplố mintegy 3200 filológiai adatot - földrajzi neveket, magyarázó megírásokat és távolságértékeket - a kormányzóság járásai szerint csoportosítva, betûrendbe szedve, többféle felsorolásban tartalmazza. A névanyaghoz kapcsolódóan egy terjedelmes adatbázis felépítésén is dolgozom. Eme munkálatok során a Laszkij térképén megjelenített terepi objektumokat és az azokhoz tartozó neveket a késôbbi kiadású térképeken is igyekszem azonosítani. Az azonosítási munkálatokhoz a 20. század második felében megjelent, 1 : 100000 és 1 : 200000 méretarányú, orosz nyelvú topográfiai térképek használatát tartom a legmegfelelôbbnek. A készülő adatbázisban a névrajzi elemek mellett egyaránt szerepelnek a pontos földrajzi helyzetükre utaló koordináták, a Laszkij-féle térképen való tájékozódást segítô keresôhálózati azonosítók, továbbá megtalálhatók benne az egyes földrajzi nevek különféle változatai, beleértve a napjainkban használt hivatalos névalakokat is

A munkálatok egyik előzetes eredményének tekinthetô, hogy a permi térképen bejelölt, ipari üzemekkel rendelkezó települések közül (a kormányzóság teljes területére nézve összesen 103 tétel) egy kivételével mindegyiket sikerült azonosítanom, és a korabeli ipari tevékenységükhöz fưződôen további - a Laszkij-féle térképrôl hiányzó - információkkal is kiegészítettem az adatbázist. A kormányzóság Kunguri járásának a térképen feltüntetett 108 települése közül mindezidáig 89-et azonosítottam, ami mintegy 82\%-os eredményt jelent. A munka befejeztével érdekes lesz megállapítani és összehasonlítani, hogy az egyes járásokat tekintve napjainkra milyen arányban maradtak fenn a korabeli települések, miként változott meg a településhálózat, valamint 


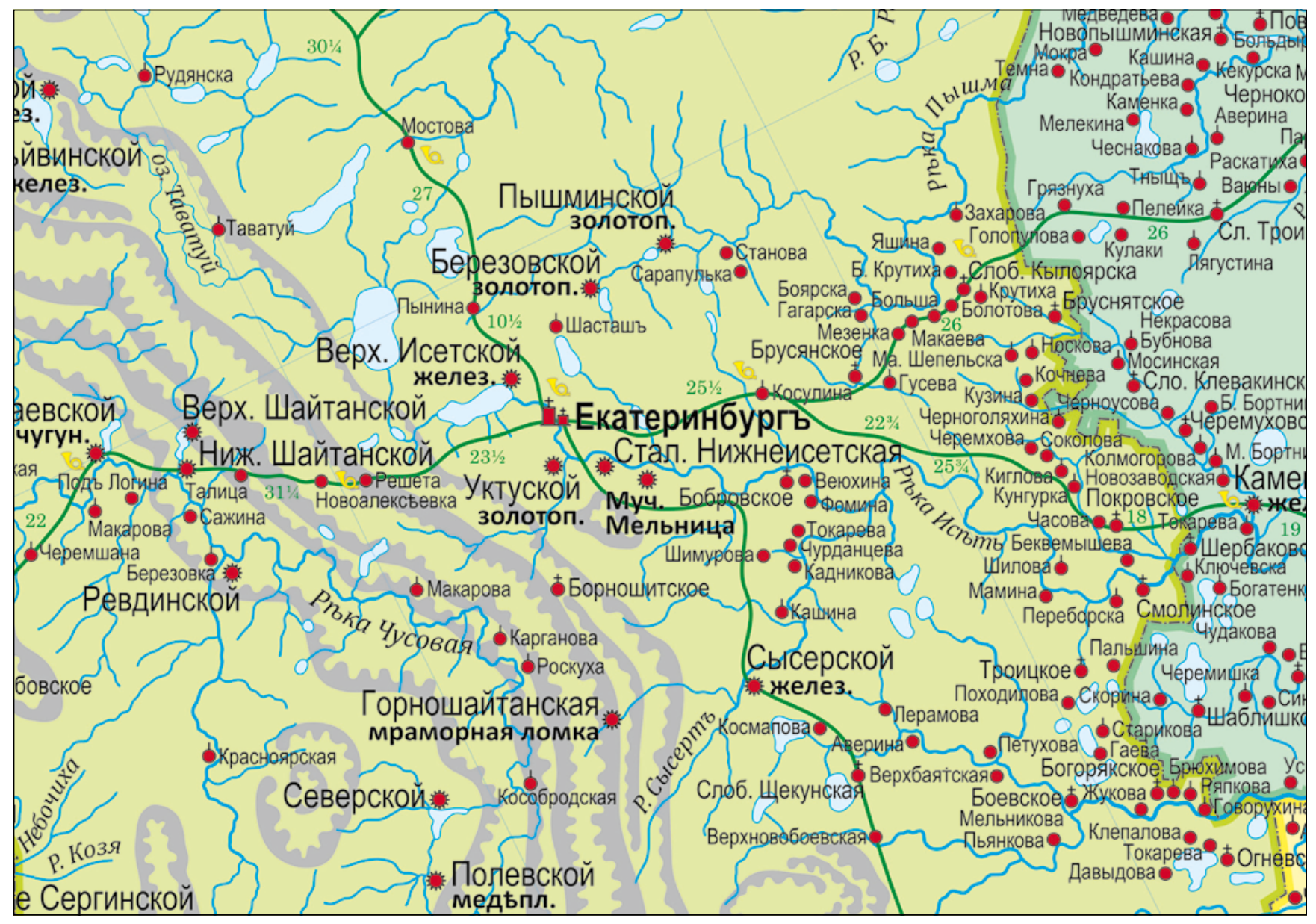

3. ábra. Jekatyerinburg és környéke a digitális fakszimile változaton

mennyire ôrzôdtek meg a víz- és településnevek, hol érhetô tetten azokban jelentôs változás a Permi kormányzóság megszúnése idején? Vagy ez a folyamat már azt megelôzóen megindult, esetleg az 1940-es években gyorsult fel? Az eddigi vizsgálatok alapján mindegyik esetre találtam példákat. A végsô összesítés során fény derülhet arra, hogy a kormányzóság területén melyik idôszakban volt leginkább jellemzô a földrajzinév-változás.

Úgy gondolom, hogy az általam összeállított vizuális és névrajzi feldolgozás hasznos segítséget jelent majd az uráli vidékeket kutató szakemberek és a térség iránt érdeklôdố közönség számára egyaránt.

\section{Összegzés}

Tanulmányomban részletesen bemutattam a hazai térképészet oldaláról mind ez idáig feltáratlannak számító Laszkijféle térképet. A 19. századi kéziratos alkotás - amely Reguly Antal hagyatékához tartozik - nagy alapossággal és tartalmi részletességgel szemlélteti a Permi kormányzóság területét, és még napjainkban is értékes forrásul szolgál az uráli vidékekhez kapcsolódó történeti-földrajzi és névtani kutatások számára.

Jelen tanulmányom célja volt az is, hogy konkrét példák megemlítésével, illetve a Laszkij-féle térkép digitális fakszimile változatának elkészítésével felhívjam a figyelmet a kartográfia alkalmazásának lehetôségére kulturális értékeink megôrzésében.

\section{Irodalomjegyzék}

Borbély Andor 1955. Reguly Antal térképének szerepe az Észak-Ural megismerésében Földrajzi Közlemények, 79. (3.) köt. 3. sz. pp. 231-241.

Gulyás Zoltán 2016. Reguly Antal térképészeti munkássága. Doktori értekezés. Kézirat. Budapest, p. 114

Klinghammer István - Gercsák Gábor 2009. Reguly Antal észak-uráli térképezése. Magyar Tudomány, 170. évf. 7. sz. pp. 858-865.

Laszkij 1843. Karta Permszkoj gubernyii. MTA Könyvtár és Információs Központ, Kézirattár: Történelem, Földrajz, 4. r. 2. sz.
Márton Mátyás 2008. A Virtuális Glóbuszok Múzeuma. Természet Világa, 139. évf. 2. különsz. pp. 74-79.

Márton Mátyás 2009. Reguly Antal és az ÉszakiUrál térképe. Geodézia és Kartográfia, 61. évf. 11. sz. pp. 20-30.

Reguly Antal 2008. Reguly Antal: Kalendárium. A magyar utazó-kutató naplója az 1843. szeptember 29. - 1846. már cius 5. közötti idốszakról Oroszországban. Pétervár - az Urál - Pétervár. Szerkesztette: Szíj Enikô. Tinta Könyvkiadó, Budapest. Rónai András (szerk.) 1993. Közép-Európa Atlasz. Szent István Társulat - Püski Kiadó, Budapest.

Zentai László 1993. A Közép-Európa Atlasz (1945) új kiadása (digitális fakszimile). Geodézia és Kartográfia, 45. évf. 6. sz. pp. 360-365.

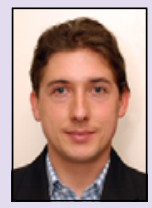

Dr. Gulyás

Zoltán

térképész, kutató

Reguly Antal Múzeum és Népi Kézmúves Alkotóház, Zirc szibir@map.elte.hu 